\title{
$\beta$-Tricalcium phosphate shaped by replica method
}

\section{(Conformação de $\beta$-fosfato tricálcico pelo método de réplicas)}

\author{
N. K. Porsani ${ }^{1}$, V. Trombini ${ }^{1}$, P. A. Ana ${ }^{2}$ L. F. G. Setz ${ }^{1 *}$ \\ ${ }^{I}$ Federal University of ABC, Center for Engineering, Modeling and Applied Social Sciences, \\ Campus Santo André, Av. dos Estados 5001, 09210-580, Santo André, SP, Brazil \\ ${ }^{2}$ Federal University of ABC, Center for Engineering, Modeling and Applied Social Sciences, \\ Campus São Bernardo do Campo, SP, Brazil
}

\begin{abstract}
Biomaterials, such as tricalcium phosphate, can have different resorption rates in the organism that depend on their physicochemical properties, where the surface condition, such as morphology, size of particles and porosity, is important. In this work, we studied the coating of natural Luffa cylindrica matrix with $\beta$-tricalcium phosphate, using the dip replica forming method, in order to adjust the surface conditions to meet the demand of bone resorption. The materials were characterized in terms of specific surface area, particle shape, imaging in electronic scanning microscope, and zeta potential in water media. The suspensions used for coating of the matrices were produced with distilled water and sodium silicate as dispersant and carboxymethyl cellulose as a binder element. Rheological measurements were performed on rotational rheometer and viscometer. The products generated with $2.5 \mathrm{wt} \%$ of sodium silicate and $0.75 \mathrm{wt} \%$ of carboxymethyl cellulose, after sintering, had pore sizes consistent with high rates of reabsorption and porosity that suggest a future use as a biomaterial.
\end{abstract}

Keywords: tricalcium phosphate, rheology, replica method shaping.

\section{Resumo}

Biomateriais, como o fosfato tricálcico, podem apresentar diferentes taxas de reabsorção no organismo que dependem das suas propriedades físico-químicas sendo que a condição superficial, tais como morfologia, tamanho de partículas e porosidade, é de fundamental importância. Assim, neste trabalho, estudou-se o recobrimento da matriz Luffa cylindrica com $\beta$-fosfato tricálcico, utilizando-se o método de conformação por réplica, de forma a adequar as condições superficiais para suprir a demanda de reabsorção óssea. Os materiais utilizados foram caracterizados em termos de área de superfície específica, forma das partículas, observação em microscópio eletrônico de varredura e potencial zeta em meio aquoso. As suspensões utilizadas nos recobrimentos das matrizes foram produzidas com água destilada e silicato de sódio como dispersante e carboximetilcelulose como elemento aglomerante. As medidas reológicas foram realizadas em viscosímetro e reômetro rotacional. Os produtos gerados com $2,5 \%$ de silicato de sódio e 0,75\% de carboximetilcelulose, após sinterização, apresentaram tamanhos de poro consistentes com altas taxas de reabsorção e porosidade adequada para uso como biomaterial.

Palavras-chave: fosfato tricálcico, reologia, conformação por réplica.

\section{INTRODUCTION}

The bone part regeneration, where there has been a loss of tissue resulting from traumas or diseases, remains a challenge because the rapid growth of connective tissue, resulting from the regenerative process, prevents or hinders the formation of new bone tissue between the lesion boundaries and the prosthesis/graft, thus, often, several repairing surgical procedures are necessary [1]. Bone defect regenerative treatments can present two types of results: healing, which is characterized by repair with the formation of a different tissue type from the tissue originally lost keeping morphology and function, and regeneration, where the

* (D) https://orcid.org/0000-0001-8984-5971 repair occurs by an identical tissue to the original preexisting one. The primary goal of surgical treatment for lost bone tissue, in many cases, is to fill the defect with a biomaterial that can promote osteoinduction, osteoconduction, and consequent reparative osteogenesis. At the current stage of knowledge, it is a consensus that autogenous bone is the most suitable biomaterial to achieve this goal. Its integration to the surrounding tissues and its osteogenesis capacity has proven superior to many other biomaterials used for the same purpose. However, its application is limited to each particular case, considering aspects such as the physical condition of the patient, the location and extent of the injury $[1,2]$. In order to overcome these limitations and also due to the great scientific and technological development, the use of synthetic biomaterials that in many cases make it possible to reduce or eliminate the use of biological tissues has received increasing attention. Thus, materials based on calcium 
phosphates, because they have excellent biocompatibility and osteoconduction, are the most used synthetic materials in bone grafting $[3,4]$.

Tricalcium phosphate (TCP) occurs in several pathological calcification processes, such as in dental and urinary calculations, occurring mainly in two allotropic forms, $\alpha$-rhombohedral and $\beta$-monoclinic $[5,6]$, that exhibit the similar ability of osteoconduction and biodegradable behavior. $\beta$-TCP is the second calcium phosphate compound more used in biomedical uses after hydroxyapatite. They can be rapidly absorbed by the organism, being used as a filler of effective bone sites, stimulating the cellular process of tissue reconstitution, providing to the grafted region the ions $\mathrm{Ca}^{2+}$ and $\mathrm{P}^{5+}$, while $\alpha$-TCP is more used in calcium phosphate cements [6]. The $\beta$-TCP in contact with SBF (simulated body fluid) solution, due to the ionic species, develops a new HAp (hydroxyapatite) phase that covers the surface material and simultaneously increases the surface pore size, indicating that the $\beta$-TCP is dissolved [7]. The development of the HAp layer on the surface of the grafted material, when subjected to the physiological conditions of the organism, shows that it is capable of replacing the originally damaged tissue. Due to this behavior both TCP allotropic alpha and beta forms have become an object of interest in the biomaterials area, being used in orthopedics and dentistry as filling material for cavities and bone defects and soft tissue anchorage [8-10].

Thus, with the knowledge of the processes of suspension shaping, using rheological concepts, it is possible to obtain suitable pieces to be used as elements of grafting or even bone prostheses [11]. Among the processes that can be used, slip casting by pouring suspensions in porous molds (usually gypsum) is a relatively simple route that allows shaping pieces with complex and sometimes massive geometries [12, 13]. The replica forming technique consists of immersion of a matrix, in mesh or sponge aspect, in a stable suspension to obtaining a product which is the replica of the original matrix [14]. The objective of this work was to obtain $\beta$-tricalcium phosphate parts, shaped by the replica method, supported by rheological concepts, to be used as grafting elements or even bone prostheses [11]. The use of the sodium silicate as dispersant in the studied suspensions is part of this work, since it can contribute to the formation of glassy phase (bioglass) on the surfaces of the TCP particles, improving osteoinductive effects [15-17]. The addition of processing additives in order to allow bioglass formation on the surface of biomaterials was found only for hydroxyapatite [18].

\section{MATERIALS AND METHODS}

The material used in the study was commercial $\beta$-tricalcium phosphate ( $\beta$-TCP, P.A., Aldrich, Germany). The specific surface area (NOVA 2200e, Quantachrome Instr., USA) was determined and particle shape was observed by scanning electron microscope (SEM, Quanta 250 , FEI, USA). The stability of tricalcium phosphate in water was determined by zeta potential, performed on Zeta PALS (Brookhaven Instr., USA). Suspensions for this determination were prepared using ultrapure water (Milli-Q, Merck Millipore, Germany) at a solid concentration of 0.01 vol\% and the $\mathrm{pH}$ was adjusted with appropriate amounts of $10^{-3} \mathrm{M} \mathrm{HCl}$ and $\mathrm{KOH}[19,20]$.

The suspensions used in this study were prepared using distilled water and sodium silicate $\left(\mathrm{Na}_{2} \mathrm{SiO}_{3}\right.$, Casa do Ceramista, Brazil) as a dispersant (defloculant). The deflocculant concentration was determined by deflocculation curve in a suspension with $60 \mathrm{wt} \%$ solid concentration. The use of this dispersant $\left(\mathrm{Na}_{2} \mathrm{SiO}_{3}\right)$ was due to the ease of being found in the market, since it is used in traditional ceramic industries [12, 21, 22], besides providing $\mathrm{SiO}_{2}$ to the studied material that can contribute to the formation of bioglass on the surfaces of the particles, improving the osteoinductive effects of tricalcium phosphate [15-17]. The possibility of bioglass formation on the surface of the particles of TCP will be studied in future works. The deflocculation curve was performed on a Brookfield type rotational analog viscometer (Q860A, Quimis, Brazil). The binding agent carboxymethyl cellulose-CMC (PA-Denver, Brazil) was added at the concentrations of $0.25 \%, 0.50 \%, 0.75 \%, 1.00 \%$ and $1.25 \%$ (wt\%) to increase the adhesion of the suspensions in the natural sponge fibers (Luffa cylindrica).

After dispersant concentration determination, the suspensions were homogenized for $24 \mathrm{~h}$ in a ball mill [23] and rheological measurements were performed on a rotational rheometer (Viscotester IQ, Thermo Haake, Germany) using concentric cylinders as a sensor. The curves were performed in controlled rate (CR) mode by increasing the shear rate from 0 to $1000 \mathrm{~s}^{-1}$, in $500 \mathrm{~s}$, maintaining at 1000 $\mathrm{s}^{-1}$ for $60 \mathrm{~s}$, returning to $0 \mathrm{~s}^{-1}$ in $500 \mathrm{~s}$ [18]. All rheological parameters, such as thixotropy values and Cross model fittings, were extracted from the flow curves obtained in the CR mode using Haake software RheoWin 4.63.0003. For each suspension produced, replicas were made with a vegetable sponge (Luffa cylindrica), which presented structured fibers in a promising way to make a macroporous ceramic. Due to the presence of substances such as lignin and cellulose, which interfere with surface adhesion [24], the sponges were treated in aqueous $2 \mathrm{wt} \% \mathrm{NaOH}$ solution for $2 \mathrm{~h}$ at $60^{\circ} \mathrm{C}$ and then washed with distilled water [25], before being used for shaping. After surface treatment, sponge samples were cut with approximately $2.5 \mathrm{~cm}$ length. The sponges impregnations were performed in two stages: in the first stage, few suspension (poorly impregnated) was used, guaranteeing the formation of a thin layer on the vegetal fibers; in the second stage, the sponges were immersed again, in a larger volume of suspension (highly impregnated) to ensure the increase of deposited layers and consequently the increase of resistance of the replica. This process was performed in triplicate. All shaped parts were oven-dried at $100^{\circ} \mathrm{C}$ for $24 \mathrm{~h}$. The thermal cycle for sintering was performed in a single step using the sequence: $150{ }^{\circ} \mathrm{C} / 8 \mathrm{~h}$, $250{ }^{\circ} \mathrm{C} / 8 \mathrm{~h}, 1000{ }^{\circ} \mathrm{C} / 2 \mathrm{~h} \mathrm{[25]}$ and $1100{ }^{\circ} \mathrm{C} / 5 \mathrm{~h}$ [26], with a heating rate of $1{ }^{\circ} \mathrm{C} / \mathrm{min}$ (microprocessed muffle, Quimis, Brazil) to avoid cracking. 


\section{RESULTS AND DISCUSSION}

TCP particle distribution and stability: the tricalcium phosphate studied showed a specific surface area of 1.375 $\mathrm{m}^{2} \cdot \mathrm{g}^{-1}$. The SEM micrograph showed that the TCP powder presented irregular shapes (Fig. 1), and particle diameters varying around $2.0 \mu \mathrm{m}$ but with agglomerated appearance, indicating that in preparing TCP suspensions the powders would need to be suitably dispersed. These parameters directly influence the behavior of the concentrated suspensions [27-29], making the effects, as dilatancy, when the viscosity increase with shear rate increment, even more pronounced in ceramic processing of suspensions with high solids concentrations ( $>65 \%$ by mass) [23] and under shear $\left(>100 \mathrm{~s}^{-1}\right)$ due to changes in the packaging factor [27].

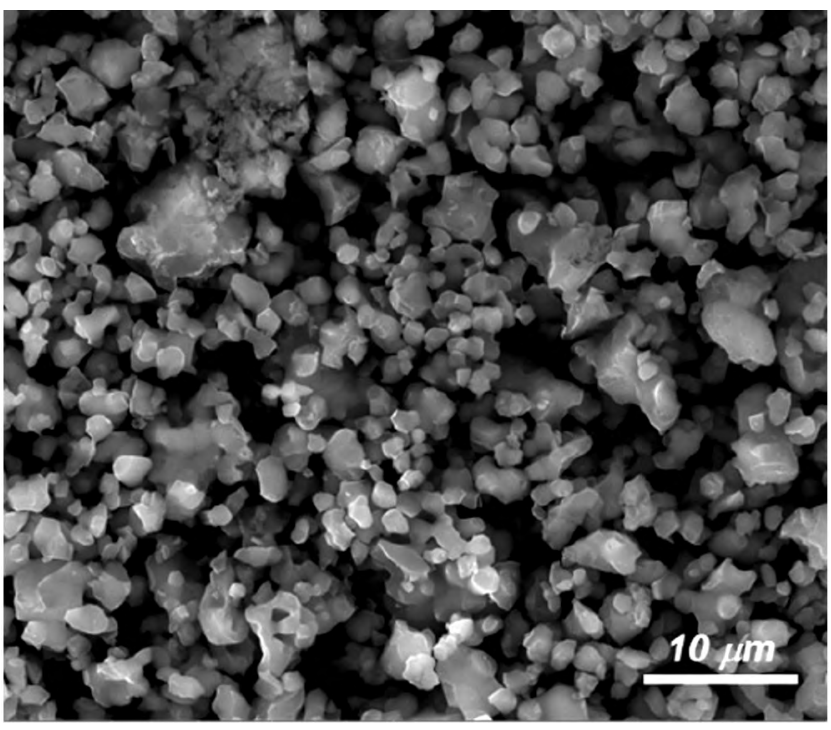

Figure 1: SEM micrograph showing agglomerate aspect of TCP particles.

[Figura 1: Micrografia de MEV ilustrando o aspecto aglomerado das partículas de TCP.]

Fig. 2 shows the zeta $(\zeta)$ potential curve of TCP in water. It was observed that the value of the isoelectric point occurred at a value close to $\mathrm{pH}$ 5, in agreement with the literature [30]. Since the stability of ceramic suspensions in aqueous media is only achieved at zeta potential values upper than $120 \mathrm{lmV}$, one must work as far away as possible from this $\mathrm{pH}$ value, that is, in this study, one must work at $\mathrm{pH}$ above $8.5[29,31$, 32]. It is important to note, moreover, that the zeta potential measurements were carried out in a suspension at low solid content $(\sim 0.01 \mathrm{vol} \%)$, where particle interactions are very low, which is a different situation in ceramic processing, in which, invariably, suspensions of high concentrations of solids are used, where there is strong interaction between the particles of the medium. Thus, sometimes the use of additives that can promote the formation of a more efficient barrier than just the electrostatic difference, minimizing interparticle attraction, is necessary $[29,31,33]$. This behavior, obtained by the use of dispersants, in this study sodium silicate, is presented as deflocculation curve in Fig. 3.

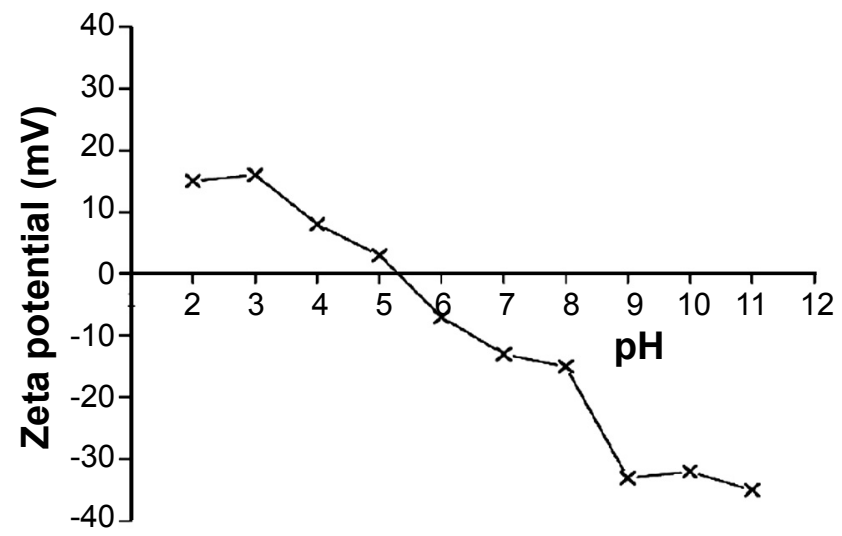

Figure 2: Zeta potential versus $\mathrm{pH}$ curve of TCP. [Figura 2: Curva de potencial zeta versus pH para TCP.]

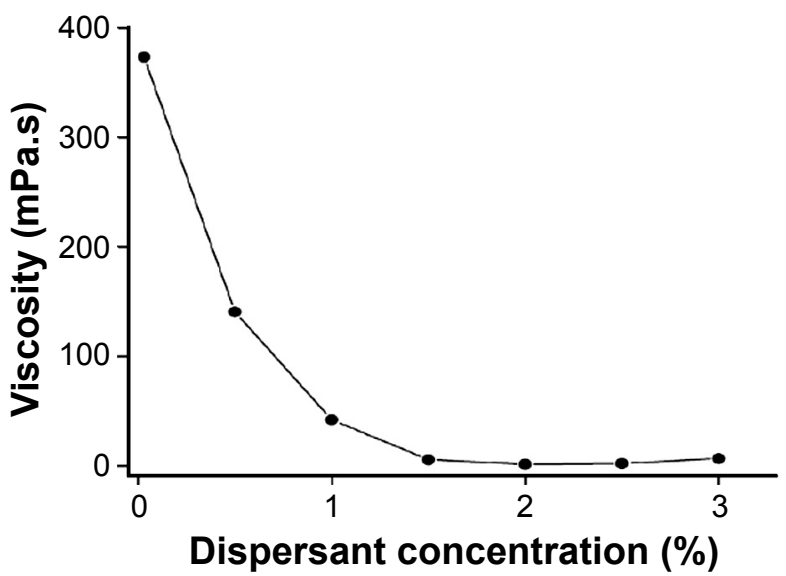

Figure 3: Aqueous deflocculation curve of TCP with sodium silicate as dispersant.

[Figura 3: Curva de defloculação de suspensões aquosas de TCP, com silicato de sódio como dispersante.]

Preparation of suspensions. Dispersant (deflocculation curve) and solids concentrations: sodium silicate is one of the most effective dispersants for ceramic products. In an aqueous medium, it is strongly alkaline and providing $\mathrm{pH}$ above 10 [34], as observed in Fig. 2, is adequate to attend a stable condition. It can be dissociated and the preferential adsorption of one type of ions onto the particle surface coupled with the formation of a diffuse layer of the counterions (ions of opposite charge) leads to electrostatic stabilization due to repulsion between the double layers. The valence and radius of the counterions can modify the repulsion between the particles and so can influence the stability of the suspension [35]. In the calcium phosphate material, there is a replacement of bivalent $\mathrm{Ca}^{2+}$ ions present on the particle surfaces by monovalent $\mathrm{Na}^{+}$ions, which produces less screening of the surface charge and, hence, a greater repulsion between the particles. The amount of dispersant required to stabilize the TCP suspensions was determined by the deflocculation curve in suspensions with solid concentration of $60 \mathrm{wt} \%$. In Fig. 3, it can be observed that there is a large reduction in the viscosity value with $0.5 \%$ dispersant, from which the viscosity 
values are reduced less intensely. This behavior, which is expected, showed that the stability increased as there was more dispersant in the system, indicating that the particles surface repulsion forces were increasing. However, the lower viscosity of the suspension and hence higher stability was obtained only with the concentration of $2.0 \mathrm{wt} \%$ sodium silicate, which remained practically constant up to $2.5 \%$ where there was then a tendency to return to rising when this dispersant concentration was exceeded. Thus, following the study, the $2.5 \%$ concentration of sodium silicate was used, so that there was enough dispersant to cover particles to be deagglomerated after homogenization in a ball mill. The suspensions, produced with distilled water and stirred in a ball mill for $24 \mathrm{~h}$ to obtain homogeneity [20,23], were then characterized in terms of flow in a rotational rheometer. The standard deviation on rheological measurements was approximately $5 \%$, as stated by the manufacturer. The slight increase in viscosity values observed from $2.5 \mathrm{wt} \%$ sodium silicate occurred due to the increase of double-layer compression by ionic concentration of the medium when the excess dispersant was added $[29,31]$.

The results of rheological analyses of the suspensions used to make the deflocculation curve are presented in Table I. The thixotropic indexes were extracted from the average values of the viscosities after turn on the apparatus $\left(\eta_{\mathrm{t} 0}\right)$ and after $10 \min \left(\eta_{t 10}\right)$. The values showed the increase of the suspension uniformity as a function of the dispersant concentration up to $2.5 \%$, in accordance with the results shown in Fig. 3. The thixotropic indexes indicated the occurrence of this phenomenon, that is, the viscosity variation with the shear time; however, it was not exactly a rheological evaluation, but an inference of the property through practical values that, in this case, was the uniformity of the flow of the suspension over time [36]. Thus, as expected and in the condition of highest uniformity (lower viscosity of the suspension), that is, with $2.0 \%$ of dispersant, the suspension showed less variation of the property with time. All thixotropic index values were less than 1.0, indicating that studied suspensions were rheopectic, that is, the suspension viscosities increased with time for the

Table I - Rheological parameters with different dispersant content.

[Tabela I - Parâmetros reológicos com diferentes concentrações de dispersante.]

\begin{tabular}{ccccc}
\hline $\begin{array}{c}\mathrm{Na}_{2} \mathrm{SiO}_{3} \\
(\mathrm{wt} \%)\end{array}$ & $\begin{array}{c}\eta_{\mathrm{t} 0} \\
(\mathrm{mPa} . \mathrm{s})\end{array}$ & $\begin{array}{c}\eta_{\mathrm{t} 10} \\
(\mathrm{mPa} . \mathrm{s})\end{array}$ & $\begin{array}{c}\text { Thixotropic } \\
\text { index }\end{array}$ & $\begin{array}{c}\text { Green density } \\
\left(\mathrm{g} . \mathrm{cm}^{-3}\right)\end{array}$ \\
\hline 0.0 & 373.1 & 527.3 & 0.71 & $42.0 \pm 2.1$ \\
0.5 & 140.3 & 253.4 & 0.55 & $49.3 \pm 1.8$ \\
1.0 & 41.7 & 132.9 & 0.31 & $52.3 \pm 4.2$ \\
1.5 & 5.3 & 86.3 & 0.06 & $49.6 \pm 2.6$ \\
2.0 & 1.1 & 67.8 & 0.02 & $48.4 \pm 3.1$ \\
2.5 & 1.8 & 73.9 & 0.02 & $50.3 \pm 1.7$ \\
3.0 & 6.3 & 102.1 & 0.06 & $48.1 \pm 2.2$ \\
\hline
\end{tabular}

same spindle rotation. In the Brookfield-type rotational viscometers, since there is no vessel with specific geometry for the measurement of viscosities, the shear rate calculation cannot be done, however, there is a direct relation with the equipment rotation [27].

The flow curves for the suspensions with different solid contents, shown in Fig. 4, exhibited a significant increment in suspension viscosities as a function of the increase in the solid concentration and was in agreement with the expected one. In ceramic processing, in general, within the parameters of each possible forming technique (slip casting, tape casting, injection, etc.), the highest possible solid content is always aimed to minimize drying problems $[12,21]$. It was observed, in addition to the predominance of dilatancy in examined suspensions, also rheopexy, corresponding to the area between the rise and fall curves of the suspensions. The latter phenomenon, as noted, was most pronounced with the increase of solid content. The distancing of these conditions during processing is always desirable [27], but, on the other hand, as these phenomena were observed in all studied suspensions, it was chosen to work with a lower solid content, around $60 \mathrm{wt} \%$, so that the occurrences of both dilatancy and rheopexy were reduced, since they reduce the shocks between the suspended particles. It was also observed that at shear rates below $300 \mathrm{~s}^{-1}$ the hysteresis almost did not exist for all studied suspensions and therefore is an indication of the best conditions to handle these suspensions. The results presented in Table II correspond to the rheological analyzes of the studied suspensions. The rheopectic behavior was observed confirming results indicated in Table I, by the negative values of thixotropy. The rheological Cross model was used to fitting all curves because it made possible to estimate the viscosities at very low shear rates, close to the rest conditions $\left(\eta_{0}\right)$ and at very high shear rates $\left(\eta_{\infty}\right)$ [29]. It is also important to note that below $300 \mathrm{~s}^{-1}$, as shown in Fig. 4, viscosity values complied with the requirements for

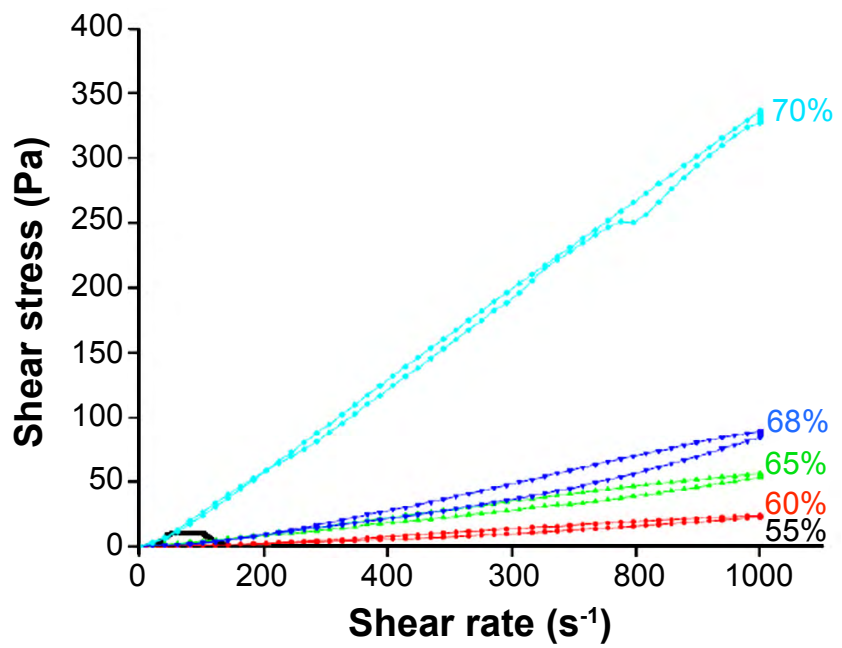

Figure 4: Viscosity curve as a function of solid content with 2.5 wt $\%$ sodium silicate as dispersant.

[Figura 4: Curvas de fluxo em função da concentração de sólidos, com 2,5\% em massa de silicato de sódio como dispersante.] 
Table II - Rheological properties for suspensions prepared with sodium silicate.

[Tabela II - Propriedades reológicas de suspensões preparadas com silicato de sódio.]

\begin{tabular}{cccccc}
\hline \multicolumn{2}{c}{ Solid conc. } & \multicolumn{2}{c}{ Cross model parameters } & Thixotropy \\
$(\mathrm{wt} \%)$ & $(\mathrm{vol} \%)$ & $\begin{array}{c}\text { Viscosity at } 0 \mathrm{~s}^{-1} \\
(\text { Pa.s })\end{array}$ & $\begin{array}{c}\text { Viscosity upper limit } \\
\text { (Pa.s) }\end{array}$ & $\begin{array}{c}\text { Viscosity at } 10 \mathrm{~s}^{-1} \\
(\text { Pa.s })\end{array}$ \\
\hline 60 & 35 & 0.026 & 0.053 & -2218 & 0.002 \\
65 & 40 & 0.050 & 0.086 & -4277 & 0.016 \\
68 & 43 & 0.072 & 0.122 & -7078 & 0.030 \\
70 & 45 & 0.276 & 0.328 & -9141 & 0.078 \\
\hline
\end{tabular}

shaping techniques such as slip casting and replica method $[12,25]$.

The viscosity curves as a function of the solid volume content, fitted by the Krieger-Dougherty model, are presented in Fig. 5. It was observed that dynamic viscosity values increased with solid content increment, reaching a maximum concentration of about $46 \mathrm{vol} \%$. When this solid concentration was reached it was observed the loss of the necessary conditions to the desired processes $[12,28,29]$. In this situation, since for forming the replica is necessary to use binder components that inflict invariably the increase in

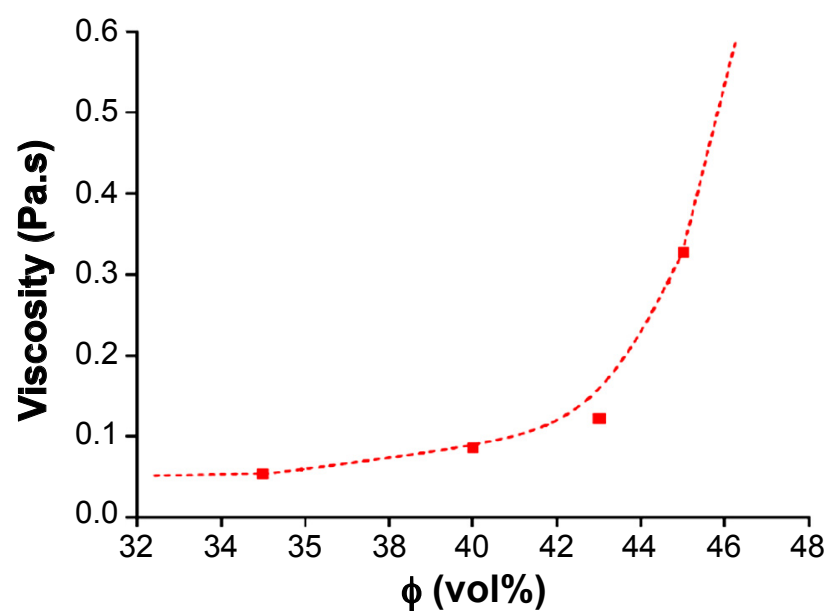

Figure 5: Viscosity curve versus solid concentration, adjusted by Krieger-Dougherty model.

[Figura 5: Curva de viscosidade versus concentração de sólidos, de acordo com modelo de Krieger-Dougherty.] viscosity of the suspensions, it was chosen a concentration of $40 \mathrm{vol} \%$ in the work sequence, with adequate viscosity to be enhanced by the addition of carboxymethyl cellulose which is a thickening element of flow [37].

Carboxymethyl cellulose concentration and replica shaping method: contrary to what was observed in deflocculated suspensions with sodium silicate, the suspensions containing carboxymethyl cellulose presented pseudoplastic behavior, caused by its polymeric structure, which at rest was randomly dispersed, but became oriented in the direction of the flow, facilitating suspension flow [38]. Despite the pseudoplasticity, the shear stresses required for the suspension to flow were higher than the stresses applied in the dispersions containing only the dispersant, confirming that the carboxymethyl cellulose can be used as a thickener. However, by this characteristic, the concentration of this additive in this study was possible up to $1.00 \mathrm{wt} \%$. Above this, homogenization and rheological measurements proved to be inadequate. With this information, knowing that 100 $\mathrm{s}^{-1}$ shear rate is a control parameter for replica shaping and the viscosity at this shear rate should be around 1 to 6 Pa.s [25], it was observed that, according to Table III, the 0.75 wt\% CMC content was the highest concentration possible to obtain replicas. With $1.00 \mathrm{wt} \% \mathrm{CMC}$, although slightly above the desired parameters, it was already sufficient to prevent proper impregnation of sponges. The values of the Cross parameters for the various carboxymethyl cellulose contents are also shown in Table III. As expected, the values increased with CMC increment, however, in the same way that the change of the behavior of dilatant to pseudoplastic occurred with the addition of carboxymethyl cellulose, the

Table III - Rheological properties of suspensions containing carboxymethyl cellulose.

[Tabela III - Propriedades reológicas de suspensões contendo carboximetilcelulose.]

\begin{tabular}{ccccc}
\hline $\begin{array}{c}\text { CMC conc. } \\
(\mathrm{wt} \%)\end{array}$ & $\begin{array}{c}\text { Cross model parameters } \\
\text { Viscosity at } 0 \mathrm{~s}^{-1} \\
\text { (Pa.s) }\end{array}$ & $\begin{array}{c}\text { Viscosity upper } \\
\text { limit (Pa.s) }\end{array}$ & $\begin{array}{c}\text { Thixotropy } \\
\left(\text { Pa.s } \mathrm{s}^{-1}\right)\end{array}$ & $\begin{array}{c}\text { Viscosity at } 100 \mathrm{~s}^{-1} \\
(\text { Pa.s })\end{array}$ \\
\hline 0.25 & 0.607 & 0.800 & 6800 & 0.425 \\
0.50 & 17.350 & 0.201 & 20030 & 1.667 \\
0.75 & 36.010 & 0.681 & 42850 & 3.887 \\
1.00 & 65.500 & 1.246 & 106400 & 8.598 \\
1.25 & 88.190 & 1.971 & 1838000 & 16.070 \\
\hline
\end{tabular}


thixotropy values observed were also modified, with an inversion of rheopectic to thixotropic behavior.

After conditioning the surface of the Luffa cylindrica sponge fibers, the impregnation of the suspensions was carried out. The amounts of the impregnated masses for each composition studied are shown in Table IV. It was observed that for $0.25 \mathrm{wt} \%$ of carboxymethyl cellulose addition the variation of the impregnated mass was low, because the suspension was still fluid and could not consistently adhere to the vegetable fiber. However, as more CMC was added, the impregnation was higher, reaching the best condition for the suspension prepared with $0.75 \mathrm{wt} \% \mathrm{CMC}$ and, thus, this was the concentration with the best workability condition, where it was possible to impregnate the fibers of the sponge without the flow of the suspension and without the obstruction of the pores. The suspension containing 1.00 wt $\%$ of CMC, due to its higher viscosity value, resulted in more difficulty in the processing, reflecting directly on the sponge macropore obstruction, undesirable for this shaping technique. The results obtained in the rheological evaluation (Fig. 6), therefore, reflected directly in the process, showing that $\mathrm{CMC}$ concentrations above $1.00 \mathrm{wt} \%$ made it unfeasible to make porous replicas by suspension impregnation. Fig. 7 illustrates the sponges after impregnation. It was observed that there were no significant visual differences at

Table IV - Mass of suspension impregnated in Luffa cylindrica sponges with different CMC concentrations.

[Tabela IV - Massa de suspensão impregnada nas esponjas Luffa cylindrica com diferentes concentrações de CMC.]

\begin{tabular}{ccc}
\hline $\begin{array}{c}\text { CMC } \\
(\mathrm{wt} \%)\end{array}$ & $\begin{array}{c}\text { Poorly impregnated } \\
(\mathrm{g})\end{array}$ & $\begin{array}{c}\text { Highly impregnated } \\
(\mathrm{g})\end{array}$ \\
\hline 0.25 & $12.1 \pm 0.7$ & $12.7 \pm 0.8$ \\
0.50 & $14.3 \pm 0.9$ & $15.9 \pm 1.1$ \\
0.75 & $13.2 \pm 1.1$ & $24.1 \pm 0.9$ \\
1.00 & $17.1 \pm 3.2$ & $19.7 \pm 2.8$ \\
\hline
\end{tabular}

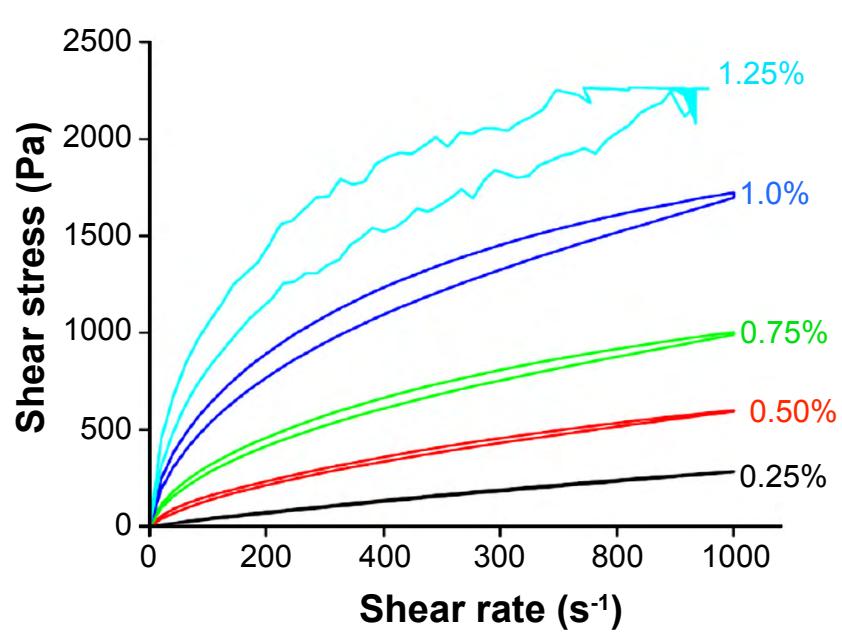

Figure 6: Viscosity curves as a function of carboxymethyl cellulose content as binder.

[Figura 6: Curvas de fluxo em função da concentração de carboximetilcelulose como aglomerante.]
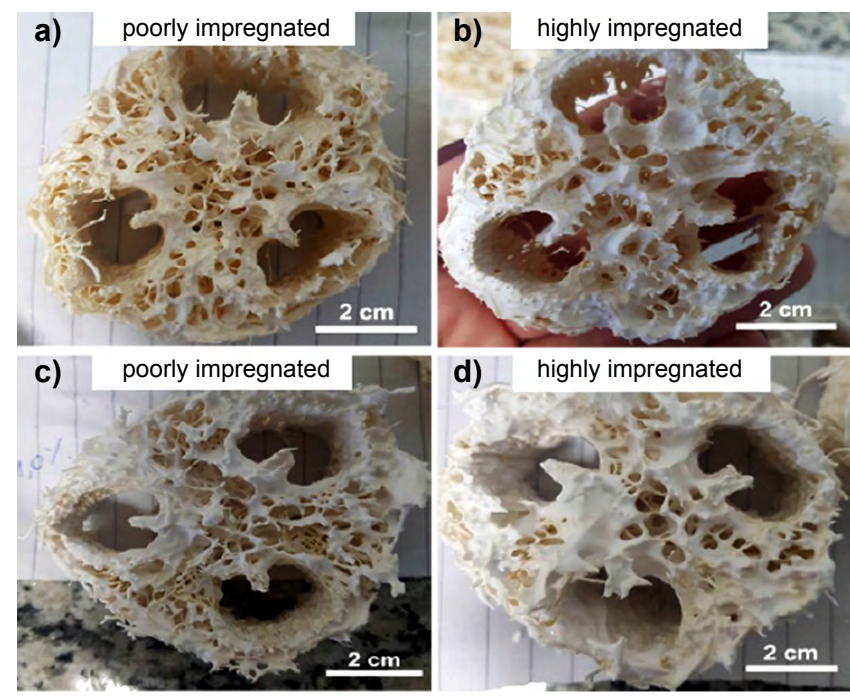

Figure 7: Luffa cylindrica sponge after impregnation with 0.75 wt\% (a,b) and $1.00 \mathrm{wt} \%$ (c,d) of CMC.

[Figura 7: Esponja Luffa cylindrica após impregnação com 0,75 $\%$ m $(a, b)$ e 1,0\%m (c,d) de CMC.]

concentrations of up to $0.75 \mathrm{wt} \% \mathrm{CMC}$, however, from $1.00 \mathrm{wt} \%$ of carboxymethyl cellulose, the pores of the sponges were filled, rendering them inadequate.

Sintering of replicas: after drying, the impregnated sponges were sintered. It was observed after the heat treatment that the specimens containing $0.25 \mathrm{wt} \%$ of CMC fragmented, while sponges impregnated with TCP suspensions with 0.50 and $0.75 \mathrm{wt} \%$ remained intact, guaranteeing mechanical resistance to the shaped replicas, however, as a result of the impregnation process, the sponges shaped with $1.00 \mathrm{wt} \%$ of CMC had closed pores. The aspects of the impregnated and sintered sponges are shown in Fig. 8. The micrographs of the sintered replicas that remained intact are shown in Fig. 9. It was observed that there was a significant variation in the grain size between the shaped specimens, increasing with increased CMC content. The intermediate condition ( $0.75 \mathrm{wt} \% \mathrm{CMC})$ presented a dense aspect with some remaining porosity, due to the better packing and impregnation conditions for this suspension. However, the remaining porosity observed due to the sponge removal process during the heat treatment was shown to be suitable for the desired application since the pores are considered small and interconnected [39, 40]. The literature shows that augmenting the number and size of pores in a biomaterial alters its reabsorption rate, increasing it significantly especially with the use of ultraporous $\beta$-TCP $[41,42]$. The increase in porosity and permeability allows for better cell adhesion and proliferation, and the microporosities (pores with diameter smaller than $10 \mu \mathrm{m}$ ) create a favorable microenvironment for the adsorption of proteins, as well as for the adhesion, proliferation and differentiation of osteoblasts [43]. Although the measurement of porosity was not objective of the present study, it was possible to observe the presence of micropores with variable diameters smaller than $10 \mu \mathrm{m}$ (Fig. 9). This fact suggested an osteoconductive property, i.e., the in vivo possibility of liquid percolation, 


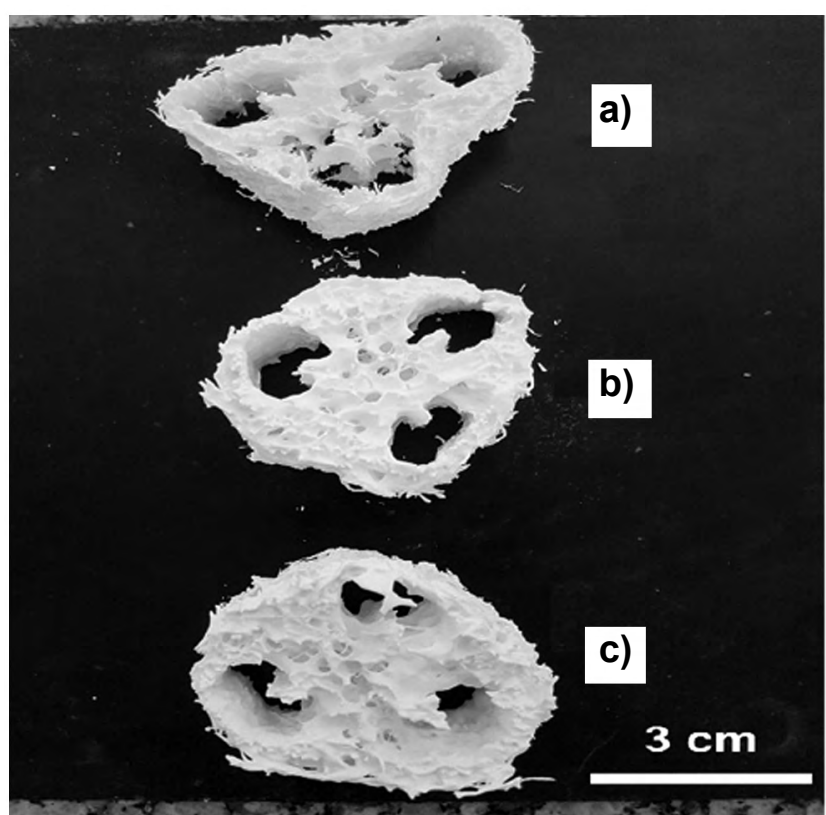

Figure 8: Impregnated and sintered sponges : a) $0.50 \mathrm{wt} \% \mathrm{CMC}$; b) $0.75 \mathrm{wt} \% \mathrm{CMC}$; and c) $1.00 \mathrm{wt} \% \mathrm{CMC}$.

[Figura 8: Esponjas impregnadas e sinterizadas: a) 0,50\%m CMC; b) 0,75\%m CMC; e c) 1,00\%m CMC.]

which facilitates the synthesis of bone matrix and consequent enhancement of bone formation. In addition to porosity, aspects such as size, morphology and structure of the grains also affect osteoinductivity and, as a consequence, the rate of reabsorption of the material. Submicrometric needleshaped particles have lower resorption rates than TCP with spherical and micrometric particles [44]. In the present study, the morphology and grain size of the proposed material suggested that it can have a higher rate of resorption when in contact with biological tissues, which indicated that it can be used in the repair of small bone lesions. Considering that the grain size and shape of biomaterial alter its cellular uptake [45], the material obtained in the present study seems to induce an inflammatory reaction, but the grains can be phagocytosed and thus do not accumulate in other parts of the body. However, future in vivo studies should be performed to evaluate the inflammatory induction of this material and the potential for effectively repairing bone defects.

\section{CONCLUSIONS}

The preparation of $\beta$-tricalcium phosphate replicas was possible using deflocculated aqueous suspensions with 2.5 wt $\%$ of sodium silicate containing $0.75 \mathrm{wt} \%$ carboxymethyl cellulose as a binder/thickener agent to ensure mechanical strength and adhesion of the suspension to the fibers of a natural sponge (Luffa cylindrica). This, however, required previous superficial treatment so that the products, after sintering, had the porosity degree and grain size necessary to reduce the reabsorption rate and be used as biomaterials. Finally, for adequate viability of the materials for bone grafting, more thorough biocompatibility results are required.

\section{ACKNOWLEDGMENTS}

The authors are gratefully acknowledged to FAPESP (Processes N ${ }^{\circ}$ 2013/09329-5, 2015/16859-6 and 2017/21887-4), CNPq (420217/2016-9) and the UFABC Multiuser Experimental Center (CEM).

\section{REFERENCES}

[1] T.J. Chambers, M.R.C. Path, Clin. Orthop. Relat. Res. 151 (1980) 283.

[2] K.J.L. Burg, S. Porter, J.F. Kellam, Biomaterials 21, 23 (2000) 2347.

[3] S.S. Dalapicula, M.B. Conz, Rev. ImplantNews 5, 2 (2008) 205.

[4] U. Almeida, J.C. Zielak, M. Filietaz, A.F. Giovanini, T.M. Deliberador, L.M. Ulbrich, C.C. Gonzaga, Odontol. Clín. Cient. 10, 3 (2011) 259.

[5] A.O. McIntosh, W.L. Jablonski, Anal. Chem. 28, 9 (1956) 1424.

[6] F.J.C. Braga, Materiais aplicados à medicina $e$ odontologia - físico-química e resposta biológica, Artliber Ed., S. Paulo (2015).

[7] D. Horkavcová, K. Zítková, D. Rohanová, A. Helebrant, Z. Cílová, Ceram. Silik. 54, 4 (2010) 398.

[8] S.-H. Kwon, Y.-K. Jun, S.-H. Hong, H.-E. Kim, J. Eur. Ceram.Soc. 23, 7 (2003) 1039.

[9] E.Y. Kawachi, C.A. Bertran, R.R. Reis, O.L. Alves, Quím. Nova 23, 4 (2000) 518.

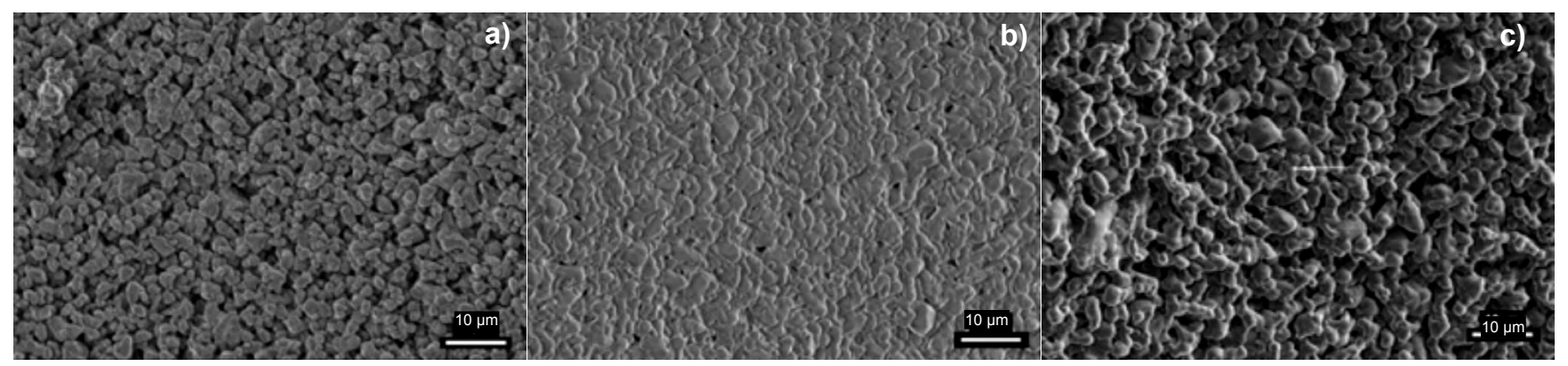

Figure 9: SEM micrographs of the impregnated and sintered TCP replicas: a) $0.50 \mathrm{wt} \%$; b) $0.75 \mathrm{wt} \%$; and c) $1.00 \mathrm{wt} \%$ of CMC.

[Figura 9: Micrografias de MEV das réplicas de TCP impregnadas e sinterizadas: a) 0,50 \% ; b) 0,75\% \% e c) 1,00 \% de CMC.] 
[10] R. Xin, Y. Leng, J. Chen, Q. Zhang, Biomater. 26, 33 (2005) 6477.

[11] H. Murata, in Polymerization, A.S. Gomes (Ed.), IntechOpen (2012) 403.

[12] J.S. Reed, Principles of ceramics processing, $2^{\text {nd }}$ ed., John Wiley Sons, New York (1995).

[13] D.W. Richerson, Modern ceramic engineering: properties, processing, and use in design, $2^{\text {nd }}$ ed., Marcel Dekker, New York (1992).

[14] S.C. Santos, "Desenvolvimento de queimadores para iluminação a gás à base de silicato de terras raras", Tese Dr., Un. S. Paulo, S. Paulo (2014).

[15] B. Fan, X.H. Wang, H. Zhang, P. Gao, H. Zhang, X. Li, H. Huang, X. Xiao, D.J. Liu, Q. Lian, Z. Guo, Z. Wang, Mater. Des. 112 (2016) 67.

[16] Y. Wan, T. Cui, W. Li, C.C. Li, J. Xiao, Y. Zhu, D. Ji, G. Xiong, H. Luo, Mater. Des. 99 (2016) 521.

[17] F. Baino, S. Fiorilli, C. Vitale-Brovarone, Acta Biomater. 42 (2016) 18.

[18] N.K. Porsani, V. Trombini, P.A. Ana, L.F.G. Setz, Cerâmica 64, 371 (2018) 325.

[19] L.F.G. Setz, S.R.H. Mello-Castanho, M.T. Colomer, R. Moreno, Solid State Ion. 180 (2009) 71.

[20] L.F.G. Setz, I. Santacruz, M.T. Colomer, S.R.H. MelloCastanho, R. Moreno, Mater. Res. Bull. 46 (2011) 983.

[21] T.A. Ring, Fundamentals of ceramic powder processing and synthesis, Academic Press, San Diego (1996).

[22] A.P.N. Oliveira, D. Hotza, Tecnologia de revestimentos cerâmicos, $2^{\text {a }}$ ed., Ed. UFSC, Florianópolis (2015).

[23] L.F.G. Setz, A.C. Silva, S.C. Santos, S.R.H. MelloCastanho, M.R. Morelli, J. Eur. Ceram. Soc. 33, 15-16 (2013) 3211.

[24] C.C.M. Fornari Jr., Fibras vegetais para compósitos poliméricos, Editus, Ilhéus (2017).

[25] S.C. Santos, C. Yamagata, A.C. Silva, L.F.G. Setz, S.R.H. Mello-Castanho, J. Ceram. Sci. Technol. 5, 3 (2014) 203.

[26] M. Spătaru, C. Ţârdei, M.R. Nemţanu, F. Bogdan, Rev. Roum. Chim. 53, 10 (2008) 955.

[27] D. Dinger, Rheology for ceramists, Dinger Ceram. Cons. Serv., Clemson (2002).
[28] T.F. Tadros, Rheology of dispersions: principles and applications, Wiley-VCH Verlag, Weinheim (2010).

[29] R. Moreno, Reología de suspensiones cerámicas, Cons. Sup. Invest. Cient., Madrid (2005).

[30] C. Ribeiro, "Obtenção e caracterização de biocerâmicas porosas à base de fosfatos de cálcio processadas com utilização de albumina", Tese Dr., Un. S. Paulo, S. Paulo (2008).

[31] J.N. Israelachvili, Intermolecular and surface forces, $2^{\text {nd }}$ ed., Acad. Press, Oxford (1992).

[32] R.J. Pugh, L. Bergström, Surface and colloid chemistry in advanced ceramics processing, Marcel Dekker, New York (1994).

[33] J.C. Berg, An introduction to interfaces and colloids: the bridge to nanoscience, World Sci. Publ. (2010).

[34] E. Kissa, Dispersions: characterization, testing, and measurement, Marcel Dekker, New York (1999).

[35] M.N. Rahaman, Ceramic processing and sintering, $2^{\text {nd }}$ ed., Marcel Dekker, New York (2003).

[36] D. Laba, Rheological properties of cosmetics and toiletries, Marcel Dekker, New York (1993).

[37] L.F.G. Setz, L. Koshimizu, A.R.F. Pardo, M.R. Morelli, Cerâmica 57, 344 (2011) 409.

[38] B.M. Cerrutti, M. Zambona, J.D. Megiatto Jr., E. Frollini, Ind. Crop. Prod. 107, 15 (2017) 54.

[39] C. Ribeiro, J.C. Bressiani, A.H.A. Bressiani, Mater. Res. 10, 3 (2007) 307.

[40] J. Kühne, R. Bartl, B. Frisch, C. Hammer, V. Jansson, M. Zimmer, Acta Orthop. Scand. 65, 3 (1994) 246.

[41] J. Brie, T. Chartier, C. Chaput, C. Delage, B. Pradeau, F. Caire, M.P. Boncoeur, J.J. Moreau, J. Craniomaxillofac. Surg. 41 (2013) 403.

[42] S. Larsson, J. Orthop. Trauma. 24 (2010) S41.

[43] B. Zanotti, N. Zingaretti, A.Verlicchi, M. Robiony, A. Alfieri, P.C. Parodi, J. Craniofac. Surg. 27, 8 (2016) 2061.

[44] R. Duan, L.A. van Dijk, D. Barbieri, F. de Groot, H. Yuan, J.D. de Bruijn, Eur. Cell Mater. 28, 37 (2019) 60.

[45] T. Lange, A.F. Schilling, F. Peters, J. Mujas, D. Wicklein, M. Amling, Biomaterials 32, 17 (2011) 4067.

(Rec. 27/01/2019, Rev. 27/02/2019, 11/04/2019, Ac. 18/04/2019) 